Ewa Migaczewska, Tomasz Masłyk Akademia Górniczo-Hutnicza w Krakowie

\title{
ETYCZNE POSTULATY VERSUS POLSKA PRAKTYKA. KONFRONTACJA DOKUMENTÓW DEONTOLOGII ZAWODOWEJ Z REALIZACJĄ ZAWODU DZIENNIKARZA
}

\section{Etyczne wyznaczniki zawodu dziennikarza - przegląd aktów deontologii zawodowej}

Etykę zawodową traktować należy jako (...) zespót norm i zasad określajacych, jak (...) powinny zachowywać się osoby tworzace dana grupę zawodowa [Zakrzewski: 2001: 217]. Deontologię stricte dziennikarską definiuje się jako ogót ocen, norm, zasad i ideałów określajacych poglady, zachowania $i$ dziatania uważane za wtaściwe, dobre, uzasadnione moralnie $w$ pracy dziennikarzy i funkcjonowaniu mediów [Pisarek: 2006: 53]. Ramy zawodu dziennikarza wyznaczać zatem winny, obok uregulowań prawnych (stanowiących wyraz obowiązującej w konkretnym społeczeństwie doktryny prasowej), unormowania o charakterze dyrektyw etycznych konstytuujaccych międzynarodowe i krajowe akty samoregulacyjne adresowane do dziennikarzy, najczęściej ujmowane w formę kodeksów etycznych. Definiuje się je jako spisane zbiory norm, zasad, postaw i zachowań uważanych za wtaściwe i moralne $w$ pracy dziennikarza, których przestrzeganie uważa się za powinność etyczna i podstawe profesjonalizmu zawodowego [Ibidem: 2006: 44].

Wśród najbardziej znaczących kodeksów rangi międzynarodowej wymienia się najczęściej Deklaracje Zasad Międzynarodowej Federacji Dziennikarzy ${ }^{1}$ uchwaloną w Bordeaux 25-28 kwietnia 1954 r. przez II Światowy Kongres Międzynarodowej Federacji Dziennikarzy (FIJ - Federation Internationale des

${ }^{1}$ Poprawki do tej Deklaracji zostały wprowadzone na XVIII Światowym Kongresie w Helsinkach 2-6 czerwca 1989 r. Tekst Deklaracji zaczerpnięty został z witryny www.dziennikarze. info/deklaracja_fed_dziennikarzy.php. 
Journalistes lub IFJ - International Federation of Journalists). Dokument kodyfikuje 9 zasad etyki zawodu dziennikarskiego:

1) poszanowanie prawdy i prawa obywateli do jej poszukiwania jest podstawowym obowiązkiem dziennikarza;

2) wypełniając ten obowiązek, dziennikarz powinien być wierny zasadom wolności poprzez rzetelne gromadzenie i publikowanie informacji; powinien też stawać w obronie prawa do swobodnego komentarza i krytyki;

3) dziennikarz może przekazywać tylko te informacje, których źródło jest mu znane. Nie wolno mu zatajać istotnej informacji lub preparować dokumentów;

4) do gromadzenia informacji, zdjęć i dokumentów dziennikarz powinien stosować wyłącznie uczciwe metody;

5) dziennikarz powinien zrobić wszystko, co w jego mocy, by sprostować opublikowaną przez siebie fałszywą informację;

6) dziennikarz powinien strzec tajemnicy źródła danej informacji;

7) dziennikarz powinien być świadomy niebezpieczeństw, jakie niosą ze sobą przejawy dyskryminacji w mediach, powinien więc unikać wyrażania dyskryminujących opinii w kwestiach płci, orientacji seksualnej, języka, religii, opinii publicznych, czy też pochodzenia społecznego lub narodowego;

8) poważnymi nadużyciami w zawodzie dziennikarza są: plagiat, złośliwe zniekształcenia faktów, kalumnie, oszczerstwa, bezpodstawne oskarżenia, przyjmowanie łapówki pod jakąkolwiek postacią (za opublikowanie bądź zatajenie informacji);

9) dziennikarz godny tego miana powinien uważać za swój obowiązek przestrzeganie wyżej wymienionych zasad. W sprawach zawodowych dziennikarze powinni respektować jedynie sądy koleżeńskie, nie poddając się jakiejkolwiek presji ze strony rządu czy innych instytucji.

Deklaracja rozumiana jest jako kodeks zawodowy dziennikarzy zajmujących się gromadzeniem, publikowaniem oraz komentowaniem informacji. Proponowane $\mathrm{w}$ niej unormowania stały się inspiracją $\mathrm{i}$ źródłem wewnętrznych uregulowań wprowadzonych w wielu krajach [por. Dobosz: 2008: 116]. W Polsce funkcjonują obecnie 2 kodeksy deontologii dziennikarskiej o charakterze regulacji stowarzyszeniowych oraz kilka dokumentów o statusie pozastowarzyszeniowym. Pierwszą grupę stanowią: Kodeks Etyki Dziennikarskiej Stowarzyszenia Dziennikarzy Polskich (SDP) oraz Dziennikarski Kodeks Obyczajowy Stowarzyszenia Dziennikarzy Rzeczypospolitej Polskiej (SD RP). KED ${ }^{2}$ w swej aktualnej wersji przyjęty został 13 października 2001 r. $^{3}$ Dokument ten, jak

${ }^{2}$ Tekst Kodeksu Etyki Dziennikarskiej SDP zaczerpnięty został z oficjalnej strony internetowej SDP (www.sdp.pl).

${ }^{3}$ Wcześniej Stowarzyszenie Dziennikarzy Polskich działało w oparciu o Dziennikarski Kodeks Obyczajowy uchwalony jeszcze w 1945 r. i zmieniony, w ramach dostosowywania jego za- 
wcześniej sygnalizowano, przyjmuje zasady zawarte w Deklaracji Międzynarodowej Federacji Dziennikarzy oraz Karcie Etycznej Mediów (o której jeszcze będzie mowa), uznając, że:

- zadaniem dziennikarzy jest przekazywanie rzetelnych i bezstronnych informacji oraz różnorodnych opinii, a także umożliwianie udziału w debacie publicznej,

- wolności słowa i wypowiedzi musi towarzyszyć odpowiedzialność za publikacje w prasie, radiu, telewizji czy Internecie,

- dobro czytelników, słuchaczy i widzów oraz dobro publiczne powinny mieć pierwszeństwo wobec interesów autora, redaktora, wydawcy lub nadawcy.

KED podzielony został na 7 rozdziałów, z których pierwszy zatytułowany Informacje $i$ opinie porusza kwestię charakteru i sposobu formułowania i prezentowania wypowiedzi dziennikarskich, drugi: Zbieranie $i$ opracowywanie materiałów poświęcony jest przede wszystkim metodom pracy dziennikarskiej podczas gromadzenia dokumentacji do publikacji (artykułu, audycji, programu), trzeci: Dziennikarz wobec rozmówców i odbiorców wprowadza listę obowiązków dziennikarzy zarówno w stosunku do bohaterów tworzonych przez nich przekazów medialnych, jak i ich potencjalnych czytelników, widzów, słuchaczy. Rozdział czwarty Przestęstwa $i$ sytuacje wyjatkowe zawiera zasady, jakimi winni kierować się dziennikarze w przypadku relacjonowania spraw karnych oraz wydarzeń szczególnych (takich, jak np. katastrofy, wypadki, wojny). Część piąta KED Konflikt interesów enumeruje czyny, których popełnienie przez dziennikarzy skutkuje utratą wiarygodności i niezależności dziennikarskiej, kategorycznie ich zabraniając. W rozdziale Koledzy i przełożeni kodeks reguluje także kwestię stosunków wewnątrzredakcyjnych. KED kończą uregulowania związane z kwestią odpowiedzialności i kar za działania naruszające jego postanowienia. A zatem Kodeks Etyki Dziennikarskiej Stowarzyszenia Dziennikarzy Polskich w sposób bardzo przejrzysty w kolejnych rozdziałach grupuje zasady związane z rozmaitymi wymiarami pracy w zawodzie dziennikarza.

Z kolei Dziennikarski Kodeks Obyczajowy Stowarzyszenia Dziennikarzy Rzeczypospolitej Polskiej (SD RP) ${ }^{4}$ przyjmuje nieco odmienną formę redakcyjną: enumeruje bowiem w sposób ciagły 10 reguł etycznych wraz z ich wykładnią oraz 5 przepisów proceduralnych, wskazujących $\mathrm{m}$. in. czyny podlegające ocenie sądownictwa dziennikarskiego. Opatrzony jest także preambuła, deklarująca, że dokument ten jest zbiorem zasadniczych norm etycznych, które obowiazuja dziennikarzy, członków Stowarzyszenia, w ich pracy $i$ działaniu zawodo-

wartości do aktualnej sytuacji społeczno-politycznej, w 1980 r. W takiej formie obowiązywał do 2001 r. [Barta, Dobosz: 1989: 117].

${ }^{4}$ Tekst Dziennikarskiego Kodeksu Obyczajowego pochodzi z oficjalnej witryny internetowej Stowarzyszenia Dziennikarzy Rzeczypospolitej Polskiej http://sdrp.eprasa.com/. 
wym. DKO uchwalony został w swej obowiązującej obecnie formie 27 września 1991 r. [Tomczyk: 1995: 59].

Analiza porównawcza Dziennikarskiego Kodeksu Obyczajowego SD RP oraz Kodeksu Etyki Dziennikarskiej SDP wskazuje na zbieżność obu dokumentów w kluczowych etycznych kwestiach związanych z zawodem dziennikarza. Wśród elementów wspólnych wskazać należy następujące wymagania nakładane na dziennikarzy, w sposób istotny konstruujące wzór normatywny ich zawodowej roli:

- poszukiwanie i publikowanie prawdy jako ich podstawowy obowiązek, przy czym KED eksponuje tę dyrektywę mniej dosłownie, za to już w preambule, a DKO w punkcie pierwszym,

- bezwzględny zakaz manipulowania przekazywanymi informacjami,

- obowiązek prostowania błędnych informacji (z własnej inicjatywy), a także przestrzegania tajemnicy zawodowej,

- zakaz czynienia przedsądów oraz uprawiania kryptoreklamy,

- zachowanie poprawności i staranności językowej, kultury języka,

- prezentowanie postawy koleżeńskości i lojalności zawodowej wobec współpracowników, przełożonych, wydawców lub nadawców (która nie może być mylona z serwilizmem - oba dokumenty podkreślają prawo dziennikarza do odmowy wykonania poleceń niezgodnych z prawem czy etyka),

- dbałość o ochronę dóbr osobistych innych osób (przy czym KED zdecydowanie bardziej szczegółowo omawia dozwolone sposoby i metody gromadzenia informacji; usprawiedliwia także ingerencję w cudzą prywatność, a nawet intymność, potrzebami dziennikarstwa śledczego, w którym dopuszcza wykorzystanie ukrytej kamery, mikrofonu czy podsłuchu telefonicznego),

- uczciwość i niezależność rozumiane jako nieprzekupność.

Jeśli natomiast idzie o różnice w zawartości obu kodeksów, dotyczą one nielicznych kwestii. DKO zawiera przepisy dotyczące ochrony praw autorskich, których nie uwzględnia KED. Kodeks SD RP (DKO) bezwzględnie zabrania dziennikarzom publikowania materiałów głoszących propagandę wojny, przemocy, gwałtu oraz naruszających uczucia religijne i osób niewierzących, uczucia narodowe, prawa człowieka i odrębności kulturowe, a także takich, które propagują pornografię. Kodeks SDP (KED) natomiast zwraca jedynie uwagę na obowiązek poszanowania praw innych osób, nie precyzując w sposób szczegółowy tego wymogu. W tym ostatnim z kolei znajduje się zapis (którego nie ma w DKO) zabraniający dziennikarzom angażowania się w działalność polityczną i partyjna, pełnienia funkcji w administracji oraz organizacjach politycznych, postrzegając tego typu aktywność za przejaw konfliktu interesów. Ostatnia sub-

${ }^{5}$ Pierwotna wersja Dziennikarskiego Kodeksu Obyczajowego SD PRL została uchwalona na I Zjeździe tej organizacji 3-5 czerwca 1988 r., a następnie zmodyfikowana na kolejnym Zjeździe 1-2 października 1987 r. [Barta, Dobosz: 1989: 117]. 
telna różnica między tymi dokumentami wiąże się z kwestią kar orzekanych za działania niezgodne $\mathrm{z}$ uregulowaniami zawartymi w kodeksach. Wśród nich DKO nie przewiduje, $w$ przeciwieństwie do KED, zawieszenia w prawach członkowskich, przechodząc od nagany do usunięcia ze Stowarzyszenia, o którym informacja ma być publikowana w periodyku lub innym wydawnictwie SD RP.

Porównanie treści ujętych w obu kodeksach pokazuje, że większość zawartych w nich zasad jest ze sobą spójna. Różnice, jeśli występują, dotyczą zwykle odmiennego poziomu uwagi przykładanej przez dany kodeks do wybranych, na pewno niekluczowych dla sposobu wykonywania zawodu dziennikarza, kwestii. Tym bardziej uzasadnione wydawałoby się podjęcie starań członków SDP i SD RP o wypracowanie jednego dokumentu. Powstanie wspólnego kodeksu etycznego obu organizacji jawi się jednak jako mało możliwe przynajmniej dopóty, dopóki utrzymywać się będzie stan konfliktu między nimi. Brak porozumienia pomiędzy stowarzyszeniami w sprawie stworzenia takiego połączonego, kolektywnego kodeksu nie przekreślił jednak możliwości przyjęcia przez nie jednego, wspólnego dokumentu o charakterze pozastowarzyszeniowym w postaci Karty Etycznej Mediów. W dniu 29 marca 1995 r. podpisali ją prezesi wszystkich stowarzyszeń dziennikarskich (obok SDP i SD RP, także Katolickiego Stowarzyszenia Dziennikarzy), a ponadto Syndykatu Dziennikarzy Polskich ${ }^{6}$, Związku Zawodowego Dziennikarzy, Unii Wydawców Prasy, Telewizji Polskiej SA, Telewizji „Polsat”, Stowarzyszenia Niezależnych Producentów Filmowych i Telewizyjnych, Polskiego Radia SA, Stowarzyszenia Radia Publicznego w Polsce, Stowarzyszenia Polskiej Prywatnej Radiofonii, Związku Zawodowego Dziennikarzy Radia i Telewizji oraz krajowy duszpasterz środowisk twórczych, ks. Wiesław Niewegłowski. Ustanowienie Karty było konsekwencją zupełnie nowych realiów, jakie powstały na rynku medialnym po 1989 r. - w przestrzeni medialnej powstał chaos aksjologiczny, który niepokoił dziennikarzy. Karta miała być wyrazem troski całego środowiska dziennikarskiego o wysokie etyczne standardy zawodowe i społeczną odpowiedzialność polskich mediów. Stanowi kwintesencję najważniejszych wyznaczników wszystkich funkcjonujących na medialnym rynku kodeksów etycznych, formułując siedem naczelnych zasad, którymi winni kierować się dziennikarze, wydawcy, producenci i nadawcy w swojej działalności zawodowej, szanując niezbywalne prawo człowieka do prawdy, kierujac się zasadq dobra wspólnego i będąc świadomymi roli mediów $w$ życiu człowieka i społeczeństwa obywatelskiego ${ }^{7}$. Należą do nich: zasada

\footnotetext{
${ }^{6}$ Syndykat Dziennikarzy Polskich powstał w listopadzie 1993 r. jako organizacja o charakterze i uprawnieniach związku zawodowego. Do organizacji związkowych należą również Związek Zawodowy Dziennikarzy i Związek Zawodowy Dziennikarzy Radia i Telewizji [Borkowska: 1996: 217-218].

${ }^{7}$ Tekst Karty Etycznej Mediów został zaczerpnięty z witryny internetowej Rady Etyki Mediów: http://www.radaetykimediow.pl/dokumenty_kmp1.html.
} 
prawdy, zasada obiektywizmu, zasada oddzielania informacji od komentarza, zasada uczciwości, zasada szacunku i tolerancji, zasada pierwszeństwa dobra odbiorcy oraz zasada wolności i odpowiedzialności. Kolejność zasad zawartych w Karcie nie ma związku z ich waga, wszystkie bowiem są istotne. Wypada podkreślić, że Karta Etyczna Mediów operuje pojęciami, które sytuują się w grupie terminów stricte filozoficznych - do takich zaliczyć bowiem trzeba dobro, prawdę, przekonania, odpowiedzialność, wolność, obiektywizm czy fakt - co w dużej mierze utrudniać może przestrzeganie zawartych w niej zasad i stwarzać pole dla swobodnej interpretacji [Pleszczyński: 2007: 114 i in.]. $\mathrm{Z}$ drugiej jednak strony, sygnalizuje rzeczywiście najważniejsze problemy etyczne związane z mediami i zawodem dziennikarza.

W dniu podpisania Karty, nazywanej czasem ,dekalogiem polskich mediów i ich pracowników" [Niewęgłowski: 1996: 30] jej sygnatariusze zawiązali Konferencję Mediów Polskich, która z kolei powołała Radę Etyki Mediów - ciała społecznego i opiniotwórczego w sprawach istotnych dla mediów i dla osób w nich zatrudnionych, czuwającego nad przestrzeganiem zasad zawartych w Karcie Etycznej Mediów ${ }^{8}$. Siedem lat później, 4 kwietnia 2002 r., członkowie Konferencji Mediów Polskich przyjęli Dziennikarski Kodeks Obyczajowy, który uznać można za rozszerzenie zasad przyjętych w Karcie Etycznej Mediów.

Dokument ten, jeśli zważyć na szeroki skład Konferencji, stanowić winien (co nie znaczy, że dzieje się tak w praktyce) do dnia dzisiejszego najbardziej powszechne unormowanie dotyczące każdego dziennikarza pracujacego $w$ polskich mediach (pkt. 28 Dziennikarskiego Kodeksu Obyczajowego ). Za nieprzestrzeganie jego postanowień oraz zasad zapisanych w Karcie Etycznej Mediów obwiniony dziennikarz odpowiada przed sądem dziennikarskim lub związkowym (pkt. $28 \mathrm{~m}$ - in fine).

${ }^{8}$ Mimo, iż Rada Etyki Mediów - zgodnie z powszechnymi oczekiwaniami, jak pisze Walery Pisarek [2004: 430] - ma czuwać nad przestrzeganiem postanowień Karty Etycznej Mediów we wszystkich środkach masowego przekazu w Polsce, powstały w niektórych mediach własne kodeksy obyczajowe (i własne instytucje mające stać na straży ich realizowania). Należą do nich dokumenty takie, jak m. in.: Zasady Etyczne Dziennikarstwa w Telewizji Publicznej, Zasady etyki zawodowej w Polskim Radiu SA, Kodeks Dobrych Praktyk Wydawców Prasy oraz inicjatywa Porozumienie „Przyjazne Media”. Ich wyczerpującą analizę znaleźć można w przytaczanej już monografii Izabeli Dobosz [2008] zatytułowanej Prawo i etyka w zawodzie dziennikarza. Istnieje również szereg kodeksów konkretnych redakcji, które nazwać można paraetycznymi [Pleszczyński: 2007: 126]. Tego typu kodeksy stanowią bowiem melanż norm etycznych, zasad profesjonalnych i zasad organizacyjnych, przyjętych przez daną redakcję. Wydaje się, że takie wewnętrzne kodeksy „firmowe” mają większe zastosowanie praktyczne niż kodeksy ogólne, roszczące sobie prawo do powszechności. Są przydatne przede wszystkim początkującym dziennikarzom, bez doświadczenia, którzy każdego dnia zaskakiwani przez trudne sytuacje stają wobec konkretnych etycznych dylematów [Day: 2006: 47].

${ }^{9}$ Tekst Dziennikarskiego Kodeksu Obyczajowego Konferencji Mediów Polskich pochodzi z witryny Rady Etyki Mediów: http://www.radaetykimediow.pl/dko.html. 
Jeśli chodzi o stronę redakcyjną, DKO KMP przypomina bardziej KED niż DKO SD RP. Składa się bowiem z preambuły (w której przeczytać można, iż kodeks został ustanowiony przez stowarzyszenia, związki zawodowe dziennikarzy oraz przez pracodawców, świadomych odpowiedzialności wobec czytelników, słuchaczy $i$ widzów i deklarujących przestrzeganie zasad Karty Etycznej Mediów) oraz 32 przepisów podzielonych na pięć rozdziałów: Zasady ogólne, Etyczne i zawodowe obowiazki dziennikarzy, Dziennikarz i pracodawca, Dziennikarz i jego koledzy oraz Postanowienia końcowe. Wszystkie zawarte w nich przepisy korespondują $\mathrm{z}$ omówionymi już uregulowaniami ujętymi w pozostałych analizowanych aktach dziennikarskiej etyki zawodowej. W tym miejscu zaznaczyć jednak warto, iż Dziennikarski Kodeks Obyczajowy Konferencji Mediów Polskich stanowi dokument dużo bardziej drobiazgowy niż wewnętrzne akty przyjęte przez polskie stowarzyszenia dziennikarskie.

Dotychczasowe rozważania poświęcone zostały analizie najważniejszych aktów deontologii dziennikarskiej, która służyć miała nakreśleniu postulowanego wzoru roli zawodowej polskiego dziennikarza. Ich podsumowanie wymaga zestawienia norm dotyczących zawodu dziennikarza konstytuujących wszystkie analizowane dokumenty etyczne. By wykaz taki uczynić jak najbardziej przejrzystym, warto posłużyć się ogólnym modelem komunikowania jako transmisji [por. Goban-Klas: 1999: 54], na który składają się podstawowe elementy triady komunikacyjnej: nadawca, przekaz oraz odbiorca (por. rys. 1). Pulę przepisów etycznych zawartych $\mathrm{w}$ badanych kodeksach etyki wyznaczających standard postępowania zawodowego dziennikarzy, podzielić bowiem można, ze względu na ich zawartość merytoryczną, na trzy grupy według wskazanych kategorii, a zatem na: zasady dotyczące postawy dziennikarza jako nadawcy oraz motywów jego działania, zasady odnoszące się do przekazu, a ściślej rzecz ujmując kryteriów selekcji materiałów i tematów oraz kryteriów przygotowania przekazu i sposobu jego przedstawiania publiczności, wreszcie zasad określających rolę dziennikarza wobec odbiorców.

I tak, na początku zaznaczyć trzeba, iż większość kwestii wszystkie analizowane dokumenty przyjmujące standardową formę kodeksu ${ }^{10}$, a zatem Dziennikarski Kodeks Obyczajowy SD RP i Kodeks Etyki Dziennikarskiej SDP oraz Dziennikarski Kodeks Obyczajowy Konferencji Mediów Polskich, regulują jeśli nie identycznie - to bardzo podobnie, tworząc spójną definicję przepisów roli zawodowej dziennikarza (por. tab. 1). Dotyczy to wszystkich trzech komponentów norm, wyróżnionych w zaproponowanym schemacie komunikowania

${ }^{10}$ Jak już sygnalizowano, Kartę Etyczną Mediów Kartę Etycznq Mediów trudno uznać za typowy kodeks etyczny. Stanowi dokument z założenia niezwykle ascetyczny bowiem starający się zawierać tylko elementarne normy etycznego działania mediów i dziennikarzy, sformułowane na tyle ogólnie, by mogły być zaakceptowane powszechnie przez wszystkie kręgi ludzi mediów, tym bardziej, że Karta nie pretenduje to roli aktu nakładającego na kogokolwiek jakiekolwiek sankcje, co nagminnie czynią kodeksy etyczne, przypominając tym samym kodeksy prawne (Pleszczyński: 2007: 114 i n.). 
nadawca-przekaz-odbiorca. W odniesieniu do pierwszego z nich, wskazać trzeba przede wszystkim na normy takie, jak:

- realizowanie zasady prawdy oraz strzeżenie wolności słowa,

- prezentowanie postawy wrażliwości na uczucia innych,

- działanie w zgodzie z własnym sumieniem oraz ugruntowanymi przekonaniami.

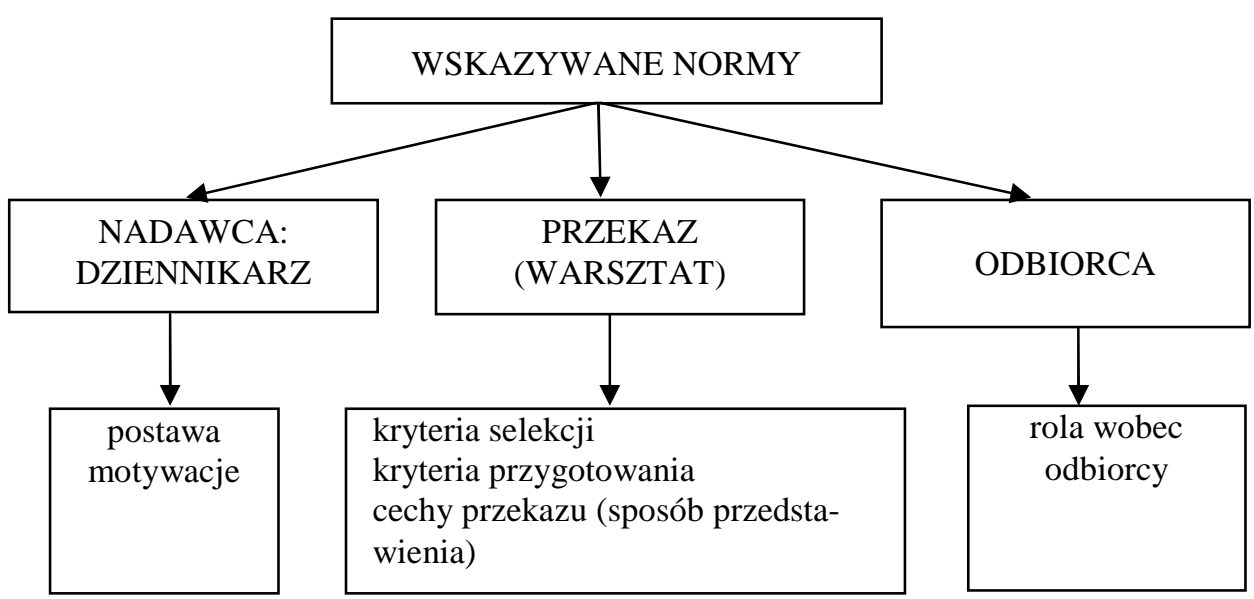

Rys. 1. Komponenty norm dotyczących zawodu dziennikarza wskazywanych w dokumentach deontologii zawodowej

Źródło: opracowanie własne.

Wśród innych wytycznych odwołujących się do kategorii dziennikarza jako nadawcy, wskazać jeszcze warto:

- wyrazistość poglądów,

- ochronę niezależności i wiarygodności zawodu oraz dobrego imienia dziennikarstwa,

- zakaz uczestnictwa w reklamie i PR oraz działalności partyjnej bądź politycznej (jakkolwiek kodeks Konferencji Mediów Polskich dopuszcza - inaczej niż KED - angażowanie się dziennikarzy w działalność polityczną, jeśli tylko oddzielą ją od pełnienia czynności zawodowych).

Wszystkie dokumenty dużą wagę przywiązują do postawy solidarności i lojalności zawodowej, podkreślając jednocześnie, że nie oznacza ona ubezwłasnowolnienia dziennikarza - zachowuje on bowiem, jak już sygnalizowano, pełne prawo do własnych poglądów i do odmowy wykonania poleceń służbowych niezgodnych z prawem lub etyką. 
Normy dotyczące zawodu dziennikarza wskazywane w dokumentach deontologii zawodowej

\begin{tabular}{|c|c|}
\hline Wymiar zawodu & Pożądane normy \\
\hline 1 & 2 \\
\hline \multicolumn{2}{|l|}{ DZIENNIKARZ } \\
\hline $\begin{array}{l}\text { Postawa/cechy } \\
\text { charakteru }\end{array}$ & $\begin{array}{l}\text { 1. wrażliwość na ludzi i ich uczucia (zwłaszcza osób niepełnospraw- } \\
\text { nych, starych lub chorych) } \\
\text { 2. wyrazistość poglądów (nieinstrumentalna) } \\
\text { 3. zgodność działań z własnym sumieniem i ugruntowanymi przekona- } \\
\text { niami } \\
\text { 4. solidarność i lojalność zawodowa (ale nie serwilizm!) } \\
\text { 5. ochrona niezależności i wiarygodności zawodu } \\
\text { 6. zakaz dyskredytowania zawodu i dobrego imienia dziennikarstwa } \\
\text { 7. powstrzymanie się od uczestnictwa w reklamie i PR oraz działalno- } \\
\text { ści politycznej lub partyjnej } \\
\text { 8. ochrona informatorów }\end{array}$ \\
\hline Motywacje & $\begin{array}{l}\text { 1. poszukiwanie prawdy i dążenie do niej } \\
\text { 2. stanie na straży wolności słowa i pluralizmu mediów }\end{array}$ \\
\hline \multicolumn{2}{|c|}{ PRZEKAZ (WARSZTAT) } \\
\hline Kryteria selekcji & $\begin{array}{l}\text { 1. niezależność } \\
\text { 2. weryfikowanie i różnicowanie źródeł informacji } \\
\text { 3. nieprzekupność (zakaz kryptoreklamy, przyjmowania prezentów, } \\
\text { lapówek, ulegania naciskom reklamodawców) } \\
\text { 4. tolerancja i akceptacja odmienności kulturowych, obyczajowych, } \\
\text { religijnych (zakaz dyskryminacji w mediach z jakiegokolwiek po- } \\
\text { wodu) } \\
\text { 5. prymat dobra odbiorców nad interesami autora lub jego zwierzchni- } \\
\text { ków } \\
\text { 6. powstrzymanie się przed eksponowaniem negatywnych wzorów } \\
\text { postępowania (grożących deprywacją zwłaszcza dzieci i młodzieży) } \\
\text { 7. powstrzymanie się od propagowania wojny i nienawiści } \\
\text { 8. powstrzymanie się od ferowania wyroków (przed orzeczeniem sądu) } \\
\text { 9. przestrzeganie linii programowej redakcji (z zachowaniem prawa } \\
\text { do własnych poglądów i odmówienia działań niezgodnych z nimi } \\
\text { lub z normami etycznymi czy prawnymi) }\end{array}$ \\
\hline $\begin{array}{l}\text { Kryteria przygoto- } \\
\text { wania }\end{array}$ & $\begin{array}{l}\text { 1. rzetelne dokumentowanie } \\
\text { 2. przyjęcie postawy niezaangażowanego obserwatora } \\
\text { 3. respektowanie praw autorskich innych (bezwzględny zakaz dokony- } \\
\text { wania plagiatów, obowiązek powoływania się na źródła) } \\
\text { 4. partnerskie traktowanie kolegów - dziennikarzy (zakaz nieuczciwej } \\
\text { konkurencji) } \\
\text { 5. poszanowanie prywatności innych (z wyłączeniem dziennikarstwa } \\
\text { śledczego) } \\
\text { 6. poszanowanie prawa innych do odmiennych poglądów } \\
\text { 7. przestrzeganie tajemnicy zawodowej } \\
\text { 8. poszanowanie praw rozmówców (m. in. prawa do autoryzacji) }\end{array}$ \\
\hline
\end{tabular}


Tabela 1 (cd.)

\begin{tabular}{|l|l|}
\hline \multicolumn{1}{|c|}{} & \multicolumn{1}{c|}{ 2 } \\
\hline & $\begin{array}{l}\text { 1. wiarygodność (m. in. prostowanie fałszywych informacji) } \\
\text { 2. rzetelność } \\
\text { 3. obiektywizm (przedstawianie rzeczywistości niezależnie od prywat- } \\
\text { nych poglądów) }\end{array}$ \\
$\begin{array}{l}\text { Sposób przedsta- } \\
\text { wienia publiczności } \\
\text { (cechy przekazu) }\end{array}$ & $\begin{array}{l}\text { 4. oddzielenie informacji od komentarza } \\
\text { opisami lub obrazami, sensacyjnymi szczegółami) }\end{array}$ \\
$\begin{array}{l}\text { 6. odpowiedzialność za słowo } \\
\text { 7. osadzanie prezentowanych wydarzeń we właściwym kontekście } \\
\text { 8. powstrzymanie się od manipulacji (oszczerstw, bezpodstawnych } \\
\text { oskarżeń, umyślnego zniekształcania faktów) }\end{array}$ \\
\hline ODBIORCA & \multicolumn{1}{|l|}{ 9. kultura języka } \\
\hline Rola wobec odbior- \\
cy
\end{tabular}

Źródło: opracowanie własne.

Jeśli chodzi o normy związane $\mathrm{z}$ przekazem, a tym samym ze sposobem wykonywania zawodu, wymienić wypada przede wszystkim powtarzające się we wszystkich kodeksach wskazówki takie, jak: zakaz manipulowania informacjami, obowiązek oddzielania informacji od komentarza, prostowanie fałszywych lub błędnych informacji, ochronę dóbr osobistych osób trzecich oraz tajemnicy zawodowej, weryfikowanie i różnicowanie źródeł informacji, tolerancję dla odmienności, zakaz epatowania przesadnie silnymi emocjami.

Wśród elementów wspólnych dla wszystkich analizowanymi dokumentów etyki zawodowej znalazły się także przepisy zakazujące dziennikarzom dokonywania plagiatów, przedsądów, kryptoreklamy. Podobnie, jak w DKO SD RP, także w DKO KMP znaleźć można zapis zakazujący dziennikarzom publikowania materiałów głoszących propagandę wojny i nienawiści, chociaż kodeks Konferencji Mediów Polskich pomija materiały propagujące pornografię. Ten ostatni zezwala też, co prawda $w$ szczególnie uzasadnionych przypadkach (pkt. 12 DKO KMP), na pokazywanie scen śmierci, co za niedopuszczalne uznał KED (przynajmniej w bliskim planie). Wydaje się, że w DKO KMP bardziej precyzyjnie niż w dwóch wcześniejszych aktach omówiona jest sprawa praw przysługujących informatorom i rozmówcom, a także odpowiedzialności zawodowej, szczególnie istotnej w przypadku wypowiedzi małoletnich. Mimo swej znacznie obszerniejszej zawartości, kodeks Konferencji Mediów Polskich, w przeciwieństwie do dwóch pozostałych dokumentów stowarzyszeniowych, nie odnosi się jednak w żadnych z punktów do kwestii poprawności i staranności językowej oraz unikania wulgaryzmów i określeń godzących w godność innych. Nie prze- 
widuje także wymiaru kar za naruszanie zasad etyki. Wskazane liczne podobieństwa, ale i różnice unormowań, przesądzają o niemożności traktowania kodeksu Konferencji Mediów Polskich jako prostego rozszerzenia jednego czy drugiego aktu stowarzyszeniowego. Tym samym, w przypadku rozbieżności zapisów, może pojawiać się problem, który z kodeksów powinien zostać uznany za uregulowanie nadrzędne w sytuacji ewentualnego procesu przed sądem dziennikarskim. Mimo zapisu, iż DKO KMP obowiązuje wszystkich dziennikarzy, brak podstaw do przyznania właśnie temu dokumentowi statusu uprzywilejowanego wobec pozostałych [Dobosz: 2008: 137]. Nie zmienia to jednak faktu, że różnice między zanalizowanymi dokumentami mają charakter kosmetyczny, natomiast w kwestiach kluczowych z punktu widzenia etycznego wymiaru zawodu dziennikarza, prezentują stanowisko wspólne. Widać to wyraźnie w treści norm dotyczących roli dziennikarza wobec odbiorcy, która we wszystkich analizowanych dokumentach deontologii zawodowej postrzegana jest jako społeczna misja, służba społeczeństwu i państwu.

Rekapitulując rozważania dotyczące postulowanego na gruncie etyki zawodowej wzoru roli zawodowej dziennikarza warto pokusić się o zdiagnozowanie w jaki sposób wśród trzech grup norm (odwołujących się do nadawcy, przekazu oraz odbiorcy) rozłożone zostały akcenty w aktach deontologii dziennikarskiej. Okazuje się, że najobszerniej i najbardziej wyczerpująco potraktowane zostały normy związane $\mathrm{z}$ warsztatem, ze sposobem realizowania czynności zawodowych, z kryteriami powstania przekazu. Oszczędniej potraktowane zostały kwestie związane z postawą dziennikarza, jego predyspozycjami i motywacjami wykonywania zawodu. Najskromniej (za to najbardziej jednoznacznie) reprezentowane są normy traktujące o funkcji, jaką dziennikarz ma spełniać wobec społeczeństwa.

Zrekonstruowany na podstawie przeprowadzonej analizy postulowany wzór roli zawodowej dziennikarza wymaga postawienia pytania o to, jak jego zasadnicze wyznaczniki związane z profesjonalizmem i prawością moralną realizowane są w praktyce dziennikarskiej, jak na co dzień etyczne przepisy roli zawodowej polscy dziennikarze wypełniają treścią. Znalezieniu odpowiedzi na te pytania posłużyła autorce analiza zawartości raportów i oświadczeń Rady Etyki Mediów wydanych w latach 2004-2008.

\section{Przegląd dziennikarskich praktyk manipulacyjnych - wnioski $z$ analizy zawartości oświadczeń i raportów Rady Etyki Mediów z lat 2004-2008}

Poddane analizie oświadczenia i raporty Rady Etyki Mediów dotyczyły zawodowego postępowania dziennikarzy zatrudnionych we wszystkich typach 
mediów. Tym samym wydaje się, iż wskazane przez REM i zanalizowane przez autorkę przypadki uznać można za reprezentatywne dla całego środowiska. Uprzedzić należy, iż przytoczone poniżej sytuacje stanowią jedynie egzemplifikację, pojedynczą ilustrację konkretnych strategii stosowanych przez polskich dziennikarzy przy wypełnianiu ich zawodowej roli, a nie wyczerpującą listę odnotowanych przez REM przypadków łamania przez tę grupę zawodową standardów profesjonalizmu i zasad etycznych.

Wśród sytuacji, które wyraźnie i dobitnie odsłoniły słabości i nadużycia polskich dziennikarzy w ostatnich latach, Rada Etyki Mediów wskazuje przede wszystkim na ich działania w szczególnie istotnym dla kraju i społeczeństwa momencie, jaki stanowią wybory prezydenckie i związana z nimi kampania. Dziennikarze, których rolą w demokratycznym państwie, jest udzielenie pomocy obywatelom w dokonaniu wyboru polityków i wyjaśnienie konsekwencji proponowanych przez nich programów, skoncentrowali się przede wszystkim na plotkach, pomówieniach i sensacjach. Koronnym przykładem takiej metody działania stało się upowszechnienie w obiegu medialnym informacji Jacka Kurskiego (sztabowca PiS), iż dziadek kandydata na prezydenta Donalda Tuska był w Wehrmachcie [Raport REM za rok 2005].

Intencjonalne upublicznienie informacji nie mających pokrycia w rzeczywistości, stanowiące kardynalne złamanie dziennikarskiej rzetelności, obliczone przede wszystkim na zwiększenie oglądalności, słuchalności i poczytności danego medium, dało także znać o sobie w działaniach dziennikarzy związanych z tzw. „listą Wildsteina”. Towarzyszące temu wydarzeniu tytuły, z których najbardziej krzywdzący dla wielu umieszczonych na niej osób: Ubecka lista krązy po Polsce, opublikowała Gazeta Wyborcza, nie tyle urzeczywistniały prawo obywateli do jawności życia publicznego, ile wprowadzały w społeczeństwie dezinformację, nasilały atmosferę wzajemnych podejrzeń i oskarżeń. Jak wynika z Raportu REM (za rok 2005), rutynową metodą postępowania wielu dziennikarzy stało się tworzenie przekazów medialnych, prezentujących rozmaite osoby, nie tylko publiczne, jako agentów SB czy tajnych współpracowników służb specjalnych, w oparciu o niepotwierdzone informacje. W nieuprawnionym ferowaniu wyroków prym wiodły zwłaszcza gazety o zasięgu terytorialnym, chociaż sprzeniewierzenia się etyce dziennikarskiej dopuszczały się także media ogólnopolskie, jak choćby tygodnik Wprost, w którym opublikowano artykuł Jakuba Urbańskiego zatytułowany Donos Pana Cogito [Wprost: 2006: nr 33-34] oskarżający Zbigniewa Herberta o współpracę z SB. Autor powołuje się w nim na bliżej niezdefiniowane dokumenty IPN, ignorując oficjalne stanowiska historyka IPN, Małgorzaty Ptasińskiej-Wójcik, która jednoznacznie stwierdziła, że poeta nie współpracował ze służbami specjalnymi PRL. W oświadczeniu REM wydanym w związku z zaistniałą sytuacją znalazła się następująca opinia: Publikacja Urbańskiego przeczy podstawowym standardom dziennikarstwa śledczego, naruszajac przede wszystkim zapisane w Karcie Etycznej Mediów zasady „szacun- 
ku i tolerancji” oraz „kierowania sie dobrem odbiorcy”. Pochopne, stabo uargumentowane, sensacyjne oskarżanie ludzi obdarzanych autorytetem moralnym przez społeczeństwo, do których należy Zbigniew Herbert, szkodzi koniecznemu odstanianiu prawdy historycznej i kompromituje niezbędny do tego proces lustracji. Wywotuje u odbiorców wrażenie, że większość znaczacych $w$ życiu publicznym PRL osób byta uwiktana we wspótpracę z systemem. Takie przeświadczenie może prowadzić do wniosku, iż rozliczanie ze skutków wspótpracy nie ma sensu (oświadczenie REM z 16 sierpnia $2006 \mathrm{r} .:$ W sprawie artykułu w tygodniku „Wprost” zawierającego oskarżenie Zbigniewa Herberta o wspótpracę z SB).

Kolejną zasługującą na miażdżącą krytykę techniką manipulacyjną stosowaną przez dziennikarzy jest coraz bardziej powszechny zwyczaj podciagania zdarzeń i wypowiedzi do z góry założonej tezy forsowanej przez autora przekazu. W przypadku gazet regionalnych często technika ta polega na podwiązywaniu się pod tzw. gwoździe numeru w mediach ogólnopolskich i poszukiwanie na swoim terenie podobnych przypadków - często nie prawdziwych, lecz wykreowanych. Przykładem wykorzystania tej techniki może być artykuł opublikowany w Nowym Kurierze Mławskim zatytułowany Cud w Mławie. W tekście znalazł się opis wydarzenia od początku do końca zmyślonego przez dziennikarza: lekarz stwierdził zgon przechodnia na ulicy, jego zwłoki zamknięto w foliowym worku, który zaczął się poruszać, bowiem, jak się okazało, uznany za zmarłego był cały i zdrowy. Publikacja ukazała się w okresie protestów lekarzy wobec niskich wynagrodzeń [Raport REM za rok 2006].

$\mathrm{Z}$ opisaną metodą działania dziennikarzy coraz częściej w ścisłym związku pozostaje inna, polegająca na kreowaniu faktów medialnych. Raport REM za 2006 r. wskazuje przykład Faktu, w którym opublikowany został artykuł o mieszkańcach Bracholina. Według relacji zamieszczonej $\mathrm{w}$ tabloidzie, na czworakach, jak zwierzęta pili oni z jeziora prawie czysty spirytus wylany do wody przez miejscową gorzelnię jako ścieki. Żeby czytelnicy nie mieli wątpliwości, że reportaż jest wiarygodny, tekst zilustrowany jest zdjęciami mężczyzn, którzy wiadrami nabierają trunek z jeziora lub na kolanach, razem z psami, pija prosto ze zbiornika. Opisane zdarzenie w całości zostało wyreżyserowane przez dziennikarza - mieszkańcy wsi pozwolili się sfotografować, bo zaoferował im 50 a nawet 70 złotych za zdjęcie, wyjaśniając jednocześnie, że kręci śmieszny film o przyrodzie.

Kolejną praktyką stosowaną przez dziennikarzy jest podawanie w serwisach informacyjnych wielu mediów wiadomości niesprawdzonych, a określanych jako pogłoski lub opatrywanych zastrzeżeniami w rodzaju: „mówi się” albo ,jak słyszeliśmy" itp. Użycie takiej formuły, w błędnym przekonaniu dziennikarzy, pozwala im przedstawiać publiczności niezweryfikowane, za to sensacyjne newsy zwiększające poczytność lub oglądalność danego medium. Tymczasem tego rodzaju asekurowanie się w praktyce nie zdejmuje z dziennikarzy odpowiedzialności za przekaz, którego nie zdołali, a często nawet nie próbowali potwier- 
dzić. W oświadczeniu REM $W$ sprawie publikowania informacji niesprawdzonych (z 1 marca 2006 r.) przeczytać można następującą ocenę społecznych skutków stosowania przez dziennikarzy opisanej metody: Taka praktyka szkodzi poważnie dobru odbiorców, znieksztatcajac obraz otaczajacej ich rzeczywistości, obniżajac poziom zaufania do wszystkich uczestników życia publicznego, zniechęcajqc obywateli do udziału $w$ tym życiu i zatruwajac klimat spotecznej debaty. $\mathrm{Z}$ przykrością skonstatować trzeba, że przecieki i pogłoski na stałe weszły do arsenału dziennikarskich metod pracy.

Wśród kolejnych praktyk dziennikarskich naruszających zasady etyki zawodowej wymienić trzeba bezpodstawne ataki na wybrane grupy zawodowe, stosowanie zasady odpowiedzialności zbiorowej oraz kreowanie ich negatywnego wizerunku w mediach. Ten sposób działania dziennikarzy, jak wynika z Raportów REM [za lata 2005, 2006, 2007 i 2008], dotknął przede wszystkim wymienianych już - przy okazji omawiania techniki tendencyjnego konstruowania przekazów - lekarzy. W ostatnim czasie najbardziej spektakularnym przykładem bezpardonowego ataku na lekarzy wydaje się sprawa aresztowania doktora Mirosława Garlickiego. Teatralizacja przekazu o jego zatrzymaniu, która przybrała skrajne formy i której dramaturgię podsycały nagłaśniane w mediach niepotwierdzone oskarżenia pod adresem lekarza (wśród nich słynne już zdanie ówczesnego ministra sprawiedliwości Zbigniewa Ziobro) wywołała lawinę publikacji na temat błędów lekarskich, stosunku służby zdrowia do pacjentów itp. Rozpoczęła się prawdziwa nagonka na lekarzy oparta o oskarżające uogólnienia, niesprawdzone relacje rzekomo pokrzywdzonych pacjentów oraz przesądzanie o winie bez prawomocnych wyroków sądu. Jak wynika z raportów REM, drugą, obok lekarzy, grupą zawodową w sposób szczególnie agresywny i często nieuzasadniony atakowaną przez dziennikarzy są sędziowie. Proceder publikowania bezpodstawnych oskarżeń wobec przedstawicieli tej profesji dał się zauważyć zarówno w pismach opiniotwórczych (np. we Wprost, Dzienniku Polska czy Gazecie Polskiej), jak i w tabloidach. Najczęściej sprowadzał się do przedstawienia motywów wyroku w sposób nierzetelny - zamiast bezstronnego wyjaśnienia i kompetentnej opinii, odbiorcom serwowano komentarz niezadowolonej strony albo opinie polityka sugerującego, że na treści wyroku zaważyły, najogólniej rzecz ujmując, względy pozamerytoryczne.

Manipulowanie słowem często wspierane jest przez odpowiedni, albo właściwiej byłoby stwierdzić, nieodpowiedni dobór zdjęcia. Przypadki ilustrowania przekazów medialnych wizerunkami osób i obrazami wydarzeń, których te przekazy nie dotyczą są w praktyce dziennikarskiej nagminne [oświadczenie REM z 28 kwietnia 2004: O mylacych zdjęciach]. Zilustrowanie materiału za wszelką cenę, nawet za cenę prawdy, dotyczy nie tylko prasy, ale także, a może należałoby skonstatować, głównie, telewizji. Zawartość tego obrazkowego medium zaspokaja przecież przede wszystkim ciekawość oczu. Zdjęcie stanowi jeden z podstawowych warunków emisji materiału. Bez ilustracji wizualnej na- 
daje się on wyłącznie do kosza. Kierując się tą regułą, za to skandalicznie omijając kwestię odpowiedzialności zawodowej, zachowali się dziennikarze polsatowskiego magazynu Interwencje - autorzy reportażu o brutalnym morderstwie emerytów z Sochaczewa. W materiale pokazano na ekranie twarze świadków zbrodni, przekazując jednocześnie informację o tym, że to właśnie oni zawiadomili policję. Ujawnienie wizerunków świadków brutalnego przestępstwa, którzy zgodzili się wypowiedzieć przed kamerą pod warunkiem zasłonięcia ich twarzy i zmiany personaliów, stanowi szczególnie rażące pogwałcenie zasad dziennikarskiej etyki zawodowej [Raport REM za rok 2006]. Demaskuje w sposób bezdyskusyjny prymat komercji nad wszelkimi wartościami konstytuującymi standardy etyki zawodowej, kwestionuje dziennikarską wiarygodność, społeczną odpowiedzialność i profesjonalizm.

Kolejną, szczególnie bulwersującą technika, związaną z wszechobecną w mediach zasadą opatrywania przekazów medialnych zdjęciami w celu zwiększenia sensacyjnej „,wartości” materiału, stosowaną przez polskich dziennikarzy, zwłaszcza tych zatrudnionych $\mathrm{w}$ tabloidach, jest zwyczaj eksponowania drastycznych zdjęć. Głośnym, nie tylko w środowisku dziennikarskim, dowodem takich praktyk było umieszczenie w Super Expressie (z 8.05.2004) zdjęcia pokazującego w zbliżeniu ciało zamordowanego dziennikarza TVP Waldemara Milewicza. Opublikowanie takiego zdjęcia stanowi rażące naruszenie jednej z podstawowych norm zawartych nie tylko we wszystkich dziennikarskich kodeksach etycznych, ale przede wszystkim obowiązujących w kulturze europejskiej, która nakazuje szacunek i dyskrecję wobec śmierci każdego człowieka. Tym samym gazeta dopuściła się pogwałcenia zasady kierowania się dobrem odbiorcy, narażając na wstrząs wrażliwość czytelników, a jednocześnie zakładając, że większość z nich pragnie i oczekuje od mediów pożywki dla tego rodzaju szokujących doznań [oświadczenie REM z 09.11.2004: W sprawie zdjęć opublikowanych $w$ Super Expressie].

Ostatnie, za to nagminne, naruszenie zasad etyki dziennikarskiej, wyinterpretowane $\mathrm{z}$ analizowanych przez autorkę raportów REM, polega na powszechnym ignorowaniu przez dziennikarzy i media obowiązku prostowania fałszywych informacji. Odmawianie zamieszczenia dementi bądź przeciaganie przez długie miesiące terminu ich publikacji staje się w Polsce plagą, obejmującą swoim zasięgiem zarówno redakcje duże, jak i małe - terenowe, z kilkunastoosobowymi zespołami. Przypadki obchodzenia tej normy etycznej można mnożyć bez końca, o czym świadczą załączane do raportów REM obszerne wykazy najbardziej charakterystycznych, typowych spraw. Skala tego zjawiska wystawia fatalne świadectwo polskim dziennikarzom. REM mówi wręcz o epidemii - pokaźny pakiet przypadków przekłamań w mediach, które nie doczekały się sprostowań, odnotowała w swoim raportach nie tylko w tabloidach: Fakcie czy Super Expressie, w których dezynwoltura dziennikarska jest nagminna, ale co gor- 
sze, także w pismach uznawanych za opiniotwórcze, takich, jak Rzeczpospolita, Gazeta Wyborcza, Newsweek czy Wprost.

Reasumując, skonstatować wypada, iż celem przeprowadzonej analizy było zdiagnozowanie sposobu realizowania roli zawodowej przez polskich dziennikarzy poprzez wskazanie praktyk, jakimi posługują się na co dzień w swojej działalności zawodowej. W oparciu o analizę oświadczeń i raportów Rady Etyki Mediów udało się stworzyć katalog dziennikarskich technik kreowania rzeczywistości, wśród których większość zasadza się na manipulacji wrażeniami odbiorców. Przestudiowane przykłady ich wykorzystania wydają się w sposób obrazowy ilustrować i wyjaśniać logikę ich działania, ujawniając jednocześnie ich sprzeczność z nawet najbardziej elementarnymi zasadami etyki zawodowej.

\section{Pomiędzy etyką a rzeczywistością - konkluzje}

Lektura raportów i oświadczeń Rady Etyki Mediów oraz przestudiowanie opisanych w nich przypadków różnego kalibru uchybień dziennikarskich wobec standardów profesjonalnych i etycznych nasuwa kilka istotnych konkluzji na temat sposobu realizowania przez polskich dziennikarzy ich zawodowej roli. Po pierwsze, w sferze zainteresowań dziennikarzy i mediów dostrzec się daje bardzo wyraźna dominacja polityki, rozrywki, sensacyjności i drastyczności nad sprawami istotnymi z punktu widzenia rozwoju społeczeństwa obywatelskiego i umacniania procedur demokratycznych. Po drugie, znikają sfery tabu - nie ma już tematów, o których nie należy pisać czy mówić. Nastapił kres wszelkiej intymności - nie ma intymności śmierci, nie ma uczucia którego nie da się sprzedać, osobistego przeżywania obcowania z sacrum, itd. Po trzecie, wyznacznikiem realnego wzoru współczesnego dziennikarstwa staje się dziś napastliwość i brutalność traktowana jako preferowany sposób podejścia do osób i wydarzeń. Po czwarte, w relacjach dziennikarskich prym wiodą tematy smutne, zjawiska naganne, patologie wypierając niemal zupełnie opisywanie jasnych stron życia społeczeństwa. Taką taktykę działania trudno uznać za budującą i krzepiącą dla obywateli. Po piate wreszcie, na podstawie przytoczonych w raportach i oświadczeniach REM przypadków, odnieść można wrażenie, iż coraz powszechniejsze w szeregach dziennikarzy staje się lekceważenie tego wymiaru profesjonalizmu, jakim jest rzetelna wiedza o tym, o czym się mówi lub pisze.

Reasumując, uznać można, iż dokonana analiza wykazała w sposób jednoznaczny całkowitą rozbieżność między rzeczywiście realizowaną formułą dziennikarstwa a postulowanym w kodeksach etyki zawodowej ujęciem roli zawodowej dziennikarza. Wydaje się, że wszystkie przytoczone wyżej wyznaczniki realizowanego dziś wzoru roli zawodowej dziennikarza są związane z tym samym faktem. Sprowadza się on do konstatacji, iż większość polskich dziennikarzy, ale i właścicieli mediów, nie rozumie, nie zna albo po prostu świadomie 
odrzuca obowiązki, jakie na nich, jako przedstawicielach zawodu, który w opinii przeważającej części społeczeństwa wymaga zaufania publicznego, ciążą, wynikające $\mathrm{z}$ unormowań zawartych w dokumentach etyki zawodowej. Te ostatnie ustępują bowiem miejsca interesom finansowym i politycznym medium bądź dziennikarskiej żądzy zysku, popularności i taniej sławy. W obronie dziennikarzy wytoczyć można jedynie argument, iż w rynkowym modelu mediów, jaki od dwóch dekad funkcjonuje w Polsce, spora część zapisów kodeksowych wydaje się zupełnie nieadekwatna do swego przedmiotu, tworząc w wielu aspektach dziennikarskiej pracy obraz wyidealizowany i oderwany od bezwzględnych reguł wolnego rynku: konkurencyjności, opłacalności i zysku. W realiach współczesnego rynku medialnego sposób wykonywania zawodu, dziennikarz dostosować musi do panujących warunków, a te dyktuje mu przede wszystkim żądny zysku pracodawca, polityk lub reklamodawca a nie dokumenty deontologii zawodowej (por. Jastrzębski: 2002: 220 i nast.). Nie zmienia to jednak faktu, iż pomimo wielu niedoskonałości, czasem wręcz utopijności niektórych zasad formułowanych w kodeksach etycznych i wątpliwości dotyczących możliwości ich praktycznego oddziaływania na środowisko - idea samoregulacji etycznej mediów uważana jest jednak wciąż za jedyny sposób zapobiegania ich nadużyciom, dający się pogodzić z nadrzędną zasadą wolności prasy [por. Golka: 1995: 22-32].

\section{Bibliografia:}

Barta Janusz, Dobosz Izabela, 1989, Prawo prasowe, Skrypty Uczelniane UJ, nr 601, wyd. II zmienione, Kraków.

Borkowska Anna, 1996, Dziennikarze i organizacje dziennikarskie, [w:] G. Kopper, I. Rutkiewicz, K. Schliep (red.), Media i dziennikarstwo w Polsce, OBP UJ, Kraków.

Day Louis A., 2006, Ethics In Media Communication. Cases and Controversies, Thomson Wadsworth, Australia, Canada, Mexico, Singapore, Spain, United Kingdom, United States, (5 ${ }^{\text {th }}$ ed.).

Dobosz Izabela, 2008, Prawo i etyka $w$ zawodzie dziennikarza, Oficyna a Wolters Kluwer Polska Sp. z o.o., Warszawa.

Goban-Klas Tomasz, 1999, Media $i$ komunikowanie masowe: teorie $i$ analizy prasy, radia, telewizji i Internetu, PWN, Warszawa-Kraków.

Golka Bartłomiej, 1995, Etyka dziennikarska: utopia czy ratunek?, „Zeszyty Prasoznawcze", nr 1-2.

Jastrzębski Jerzy, 2002, Kodeksy etyki dziennikarskiej jako narzędzie promowania własnego środowiska, [w:] I. Borkowski, A. Woźny (red.), W lustrze. Wizerunek mediów wtasny, Oficyna Wydawnicza Arboretum, Warszawa. 
Niewęgłowski Wiesław, 1996, Dziennikarz - nosiciel integralnej wizji człowieka i świata, [w:] Z. Kobylińska, R. D. Grabowski (red.), Dziennikarski etos. Zwybranych zagadnień deontologii dziennikarskiej, Wydawnictwo Lux Mundi, Olsztyn.

Pisarek Walery, 2004, Kodeksy etyki dziennikarskiej, [w:] Z. Bauer, E. Chudziński (red.), Dziennikarstwo i świat mediów, Universitas, Kraków.

Pisarek Walery (red.), 2006, Słownik terminologii medialnej, Universitas, Kraków.

Pleszczyński Jan, 2007, Etyka dziennikarska, Difin, Warszawa.

Tomczyk R., 1995, Etyka dziennikarska w świetle orzecznictwa Naczelnego Sqdu Dziennikarskiego SD RP, ,Zeszyty Prasoznawcze”, nr 1-2.

Zakrzewski Stanisław, 2001, Etyka dziennikarska, [w:] A. Niczyperowicz (red.), Dziennikarstwo od kuchni, Wydawnictwo TS, Poznań.

\section{Wykaz cytowanych dokumentów zastanych poddanych analizie:}

Deklaracja Zasad Międzynarodowej Federacji Dziennikarzy.

Dziennikarski Kodeks Obyczajowy Konferencji Mediów Polskich.

Dziennikarski Kodeks Obyczajowy Stowarzyszenia Dziennikarzy Rzeczypospolitej Polskiej.

Karta Etyczna Mediów.

Kodeks Etyki Dziennikarskiej Stowarzyszenia Dziennikarzy Polskich.

Oświadczenie Rady Etyki Mediów z 28 kwietnia 2004 r.: O mylacych zdjęciach.

Oświadczenie Rady Etyki Mediów z 9 listopada 2004 r.: W sprawie zdjęć opublikowanych w Super Expressie.

Oświadczenie Rady Etyki Mediów z 16 sierpnia 2006 r.: W sprawie artykułu w tygodniku „Wprost” zawierajacego oskarżenie Zbigniewa Herberta o wspótprace z $S B$.

Raport Rady Etyki Mediów za rok 2005.

Raport Rady Etyki Mediów za rok 2006.

Raport Rady Etyki Mediów za okres: za okres: styczeń 2007-maj 2008.

\section{Wykaz cytowanych witryn internetowych:}

www.dziennikarze.info/deklaracja_fed_dziennikarzy.php.

www.sdp.pl.

www. ifj.org.fr.

WwW.radaetykimediow.pl/dokumenty_kmp1.html.

www.sdrp.eprasa.com. 


\title{
ETHICAL DEMANDS VERSUS THE POLISH PRACTICE. CONFRONTATION OF DOCUMENTS OF THE PROFESSIONAL DEONTOLOGY WITH THE REALIZATION OF THE JOURNALIST'S PROFESSION
}

\begin{abstract}
Summary
The article aims at comparing the image of the journalist resulting from ethical codes with the real way of carrying the professional role out. The text is to show the distance which is separating ethical demands from the practice. The conclusions resulting from the content analysis of the ethical codes of journalistic associations and other acts of the professional deontology will be confronted with methods indeed applied by journalists. They will be recognized based on analysis of the content of chosen declarations and reports of The Council of Media Ethics in the period 2004-2008.
\end{abstract}

Key words: journalist, professional deontology, journalistic strategies of creating reality. 